\title{
Comparison of red cell distribution width and a red cell discriminant function incorporating volume dispersion for distinguishing iron deficiency from beta thalassemia trait in patients with microcytosis
}

Department of Clinical Medicine and Hemocentro, Department of Clinical Pathology, Faculty of Medical Sciences, University of Campinas - Campinas, Brazil

\begin{abstract}
The red cell distribution width (RDW), and another red cell discriminant function incorporating RDW $\left(\mathrm{MCV}^{2} \times \mathrm{RDW} / \mathrm{Hgb} \times 100\right)$ were determined in a group of 30 patients with iron deficiency anemia, 30 patients with beta thalassemia trait, and 30 normal subjects. Both RDW and $\left(\mathrm{MCV}^{2} \times \mathrm{RDW} / \mathrm{Hgb} \times 100\right)$ mean values were significantly higher in iron deficiency anemia than in beta thalassemia trait $(\mathrm{p}<0.001)$. Taking RDW equal or above 21.0 percent among microcytic anemia patients, we identified correctly 90.0 percent of patients with iron deficiency anemia. The sensitivity and specificity of the test were 90.0 percent (IC 95 percent: $0.75-0.96$ ) and 77.0 percent (IC 95 percent: $0.60-0.88$ ), respectively. RDW values below 21.0 percent identified correctly 77.0 percent of beta thalassemia trait with a sensitivity and a specificity of 77.0 percent (IC 95 percent: $0.60-0.88$ ) and 90.0 percent (IC 95 percent: $0.75-0.96$ ), respectively. Taking values of $\left(\mathrm{MCV}^{2} \times \mathrm{RDW} / \mathrm{Hgb} \times 100\right)$ above and below 80.0 percent as indicative of iron deficiency and beta thalassemia trait, respectively, we identified correctly 97.0 percent of those patients in each group. Both sensitivity and specificity were 97.0 percent (IC 95 percent: $0.84-0.99$ ). These results indicated that the red cell discriminant function incorporating volume dispersion $\left(\mathrm{MCV}^{2} \times \mathrm{RDW} / \mathrm{Hgb} \times 100\right)$ is a highly sensitive and specific method in the initial screening of patients with microcytic anemia and is better than RDW in differentiating iron deficiency anemia from beta thalassemia trait.
\end{abstract}

UNITERMS: Microcytic anemia. Red cell discriminant function.

\section{INTRODUCTION}

I ron deficiency is widespread throughout the world and it is probably the most common chronic organic malady of human kind. On the other hand, in many parts of

\author{
Adress for correspondence: \\ Sara Teresinha Ollala Saad \\ Hemocentro/UNICAMP \\ Caixa Postal 6198 \\ Campinas/SP - Brasil - CEP 13081-970
}

the world, the frequency of beta thalassemia is second only to that of iron deficiency as a cause of hypochromic microcytic anemia. Although severe forms of beta thalassemia, in general, are easily recognized, milder forms may be misdiagnosed and treated as iron deficiency. ${ }^{1.2}$ Several screening methods, obtained from the generation of red blood cell indices by electronic counters, have been proposed to differentiate iron deficiency from beta thalassemia trait. ${ }^{3-8}$ The usefulness of red blood cell distribution width (RDW), an index of red blood cell size heterogeneity, in the classification and work up of microcytic anemias has been documented. ${ }^{3.9-12}$ 
Another red cell discriminant function (MCV2 $\mathrm{x}$ RDW/Hgb x 100) was described by Green and King (1989). According to these authors, the use of this parameter results in enhanced accuracy in distinguishing iron deficiency anemia from beta thalassemia trait. The purpose of this study was to assess the clinical utility of each one of these approaches in differentiating these types of anemia. Determinations of serum iron, transferrin, ferritin and hemoglobin eletrophoresis were used to determine the diagnosis of these anemias.

\section{MATERIALS AND METHODS}

We studied 60 patients with mild microcytic anemia (30 with iron deficiency anemia and 30 with beta thalassemia trait), seen at the University Hospital of Campinas. The patients presented hemoglobin $(\mathrm{Hgb})$ levels above $8 \mathrm{~g} / \mathrm{dL}$ : below $12 \mathrm{~g} / \mathrm{dL}$ for females; above $8 \mathrm{~g} / \mathrm{dL}$ and below $14 \mathrm{~g} / \mathrm{dL}$ for males and $\mathrm{MCV}<80 \mathrm{fl}$. The set consisted of 30 patients with iron deficiency anemia and 30 patients with beta thalassemia trait. Thirty blood donors with normal Hgb levels (12-16 g/dL for females, $14-18 \mathrm{~g} / \mathrm{dL}$ for males) and MCV 80-94 fl were taking as controls.

The diagnosis of iron deficiency was based on the determination of serum iron, serum total iron binding capacity, and serum ferritin. Serum iron and serum total iron binding capacity were determined by colorimetric method (Labtest diagnóstica). Serum ferritin was determined using enzyme imunoassay (Stratus ferritin fluorometric enzyme immunoassay - Baxter Diagnostics Inc., USA). The diagnosis of iron deficiency was established if serum iron was below $37 \mu \mathrm{g} / \mathrm{dL}$ for females, and below $45 \mu \mathrm{g} / \mathrm{dL}$ for males. Serum total iron binding capacity was above $390 \mu \mathrm{g} / \mathrm{dL}$, and serum ferritin was below $10 \mathrm{ng} / \mathrm{dL}$ for females and below $30 \mathrm{ng} / \mathrm{dL}$ for males. Hemoglobin eletrophoresis was performed on cellulose acetate membrane, $\mathrm{pH} 8.6$ and $\mathrm{Hgb} \mathrm{A} 2$ was eluted for quantitation. ${ }^{13}$ The diagnosis of beta thalassemia trait was made if $\mathrm{Hb} \mathrm{A} 2$ value was above 3.4 percent. RDW and red cell discriminant function (MCV2 $\times \mathrm{RDW} / \mathrm{Hgb} \times 100$ ) were obtained from blood counts carried out using an automated instrument (Cell-Dyn, Model 1600 CS).

Optimal diagnostic levels for each system were established on the basis of sensitivity and specificity of values obtained from various decision levels, empirically determined. The significances of differences between groups were determined by the Mann Whitney test. ${ }^{14}$ The confidence intervals were determined according to Simon. ${ }^{15}$

\section{RESULTS}

The distributions of values of RDW and $\left(\mathrm{MCV}^{2} \mathrm{x}\right.$ $\mathrm{RDW} / \mathrm{Hgb} \times 100)$ in 30 patients with iron deficiency anemia, 30 patients with beta thalassemia trait and 30 controls are shown in Figure 1 and 2.

The mean values of RDW in iron deficiency were significantly higher than in beta thalassemia trait $(24.3 \pm$ 4.0 vs $20.0 \pm 1.3 ; \mathrm{p}<0.001)$. The mean RDW controls was lower $(15.7 \pm 0.7)$ than the values observed in iron deficiency anemia and beta thalassemia trait $(\mathrm{p}<0.001)$. RDW above 24.0 percent was observed only in iron deficiency, comprising 43.0 percent of this population. On the other hand, values below 20.0 percent were observed only in beta thalassemia trait, comprising 60.0 percent of these patients.

The mean values of the red cell discriminant function incorporating volume dispersion $\left(\mathrm{MCV}^{2} \times \mathrm{RDW} / \mathrm{Hgb} \times\right.$ 100) were significantly higher in iron deficiency than in beta thalassemia trait $(108.0 \pm 17.3$ and $68.0 \pm 5.7$, respectively; $\mathrm{p}<0.001)$ or than in normal subjects $(86.5 \pm$ $9.1 ; \mathrm{p}<0.001)$. This index was significantly lower in beta

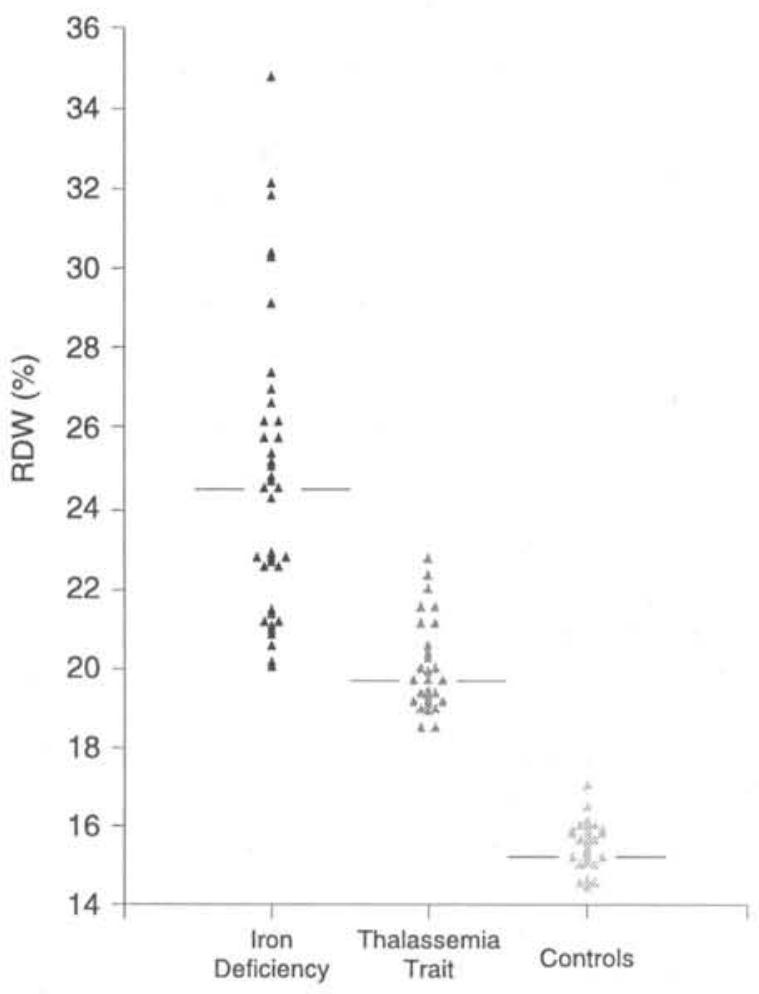

Figure 1 - Distribution of the values of RDW in 30 patients with iron deficiency anemia, 30 patients with beta thalassemia trait and 30 controls. 
thalassemia trait than in normal subjects $(\mathrm{p}<0.001)$. When microcytic anemia was considered, values above 85.0 percent were observed only in iron deficiency anemia, comprising 90.0 percent of this population and values below 75.0 percent were observed only in beta thalassemia trait, including 83.0 percent of this population. These results are represented in Figure 3.

On the basis of the maximum sensitivity and specificity we chose, as discriminant, the values of 21.0 percent for RDW and 80.0 percent for $\left(\mathrm{MCV}^{2} \times \mathrm{RDW} /\right.$ $\mathrm{Hgb} \times 100$ ). The proportions of correctly identified patients according to these decision levels are shown in Table 1. Among microcytic anemia patients, RDW values equal or above 21.0 percent were indicative of iron deficiency with the sensitivity of 90.0 percent (IC 95 percent: $0.75-0.96$ ) and specificity of 77.0 percent (IC 95 percent: $0.60-0.88$ ). RDW values below 21.0 percent were indicative of beta thalassemia trait with the sensitivity of 77.0 percent (IC 95 percent: $0.60-0.88)$ and specificity of 90.0 percent (IC 95 percent: $0.75-0.96)$. $\left(\mathrm{MCV}^{2} \times \mathrm{RDW} / \mathrm{Hgb} \times 100\right)$ equal or above 80.0 percent were indicative of iron deficiency anemia, while values below 80.0 percent were indicative of beta thalassemia trait and both sensitivity and specificity were 97.0 percent (IC 95 percent: $0.84-0.99$ ).

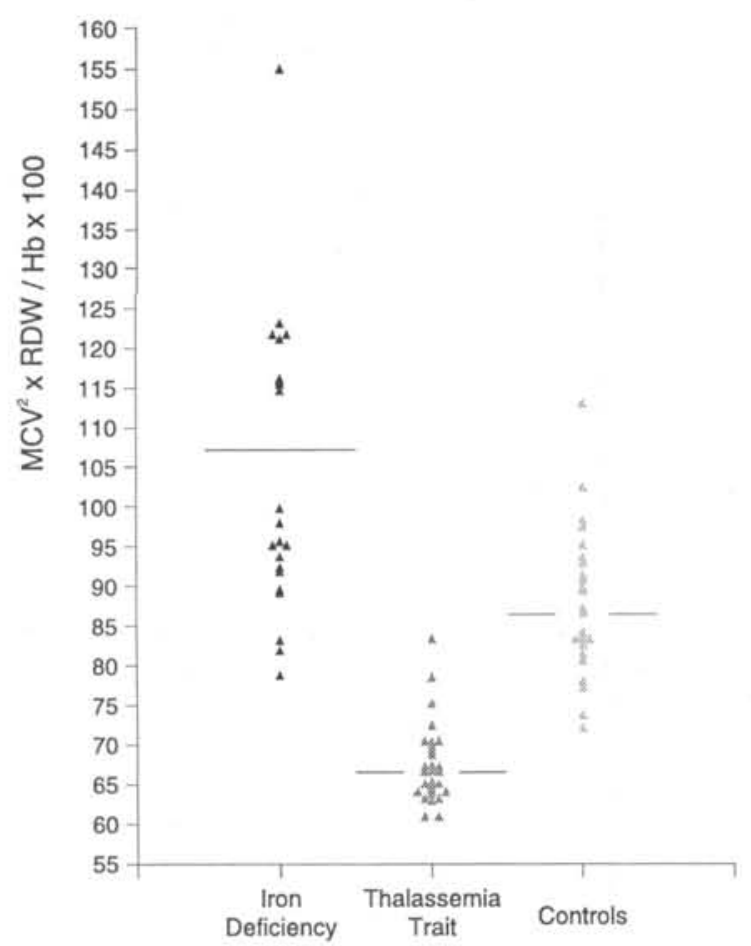

Figure 2 - Distribution of the values of $\left(\mathrm{MCV}^{2} \times \mathrm{RDW} / \mathrm{Hgb} \times 100\right)$ in 30 patients with iron deficiency anemia, 30 patients with beta thalassemia trait and 30 controls.

\section{DISCUSSION}

Microcytosis is a classical laboratory feature of the disorders of hemoglobin synthesis, such as iron deficiency and beta thalassemia trait. Because of the high frequency of these abnormalities in several populations, many screening methods have been described as to differentiate both disorders. ${ }^{2-6,16}$ Most of them are based on the fact that, in iron deficiency anemia, the anisocytosis is more predominent than in beta thalassemia trait. Microcytosis is usually more predominent in beta thalassemia trait than in iron deficiency and it is proportional to the degree of anemia in iron deficiency.

In this study, the mean values of RDW observed in iron deficiency were significantly higher than in beta thalassemia trait. This result can be explained by the fact that anisocytosis found in iron deficiency anemia is due to the coexistence, in peripheral blood, of red cells produced in the bone marrow during progressive degrees of iron deficiency, giving rise to a mixed population of normocytic and increasingly microcytic cells. In beta thalassemia trait, there is no fluctuations in the underlying disorder and the bone marrow produces a uniform population of microcytic cells. . $^{3.9 .12 .17}$

Based on the major values of both sensitivity and specificity, we chose different decision levels of RDW, and of the red cell discriminant function incorporating volume dispersion for distinguishing iron deficiency from beta thalassemia trait. Thus, among microcytic anemia patients, values of RDW above 24.0 percent and below 20.0 percent were observed only in iron deficiency anemia and beta thalassemia trait, respectively, comprising about an half of each population. However, 90.0 percent of patients with iron deficiency anemia and 77.0 percent of beta thalassemia minor patients were correctly identified using RDW values above or below 21.0 percent, respectively. Thus, this discriminant function seem to be a sensitive and specific method to identify iron deficiency among microcytic anemia patients, although it was not a good index for the identification of beta thalassemia trait. Thus a clear distinction between these disorders cannot be made based on RDW alone.

On the other hand, the mean values of the Green and King index were significantly higher in iron deficiency anemia than in beta thalassemia trait. Among subjects with microcytosis, values of this discrimant function above 85.0 percent and below 75.0 percent were observed only in iron deficiency and beta thalassemia trait, respectively, composing 90.0 percent and 83.0 percent of each population. The Green and King index above or below 80.0 percent identified correctly 97.0 percent of patients 

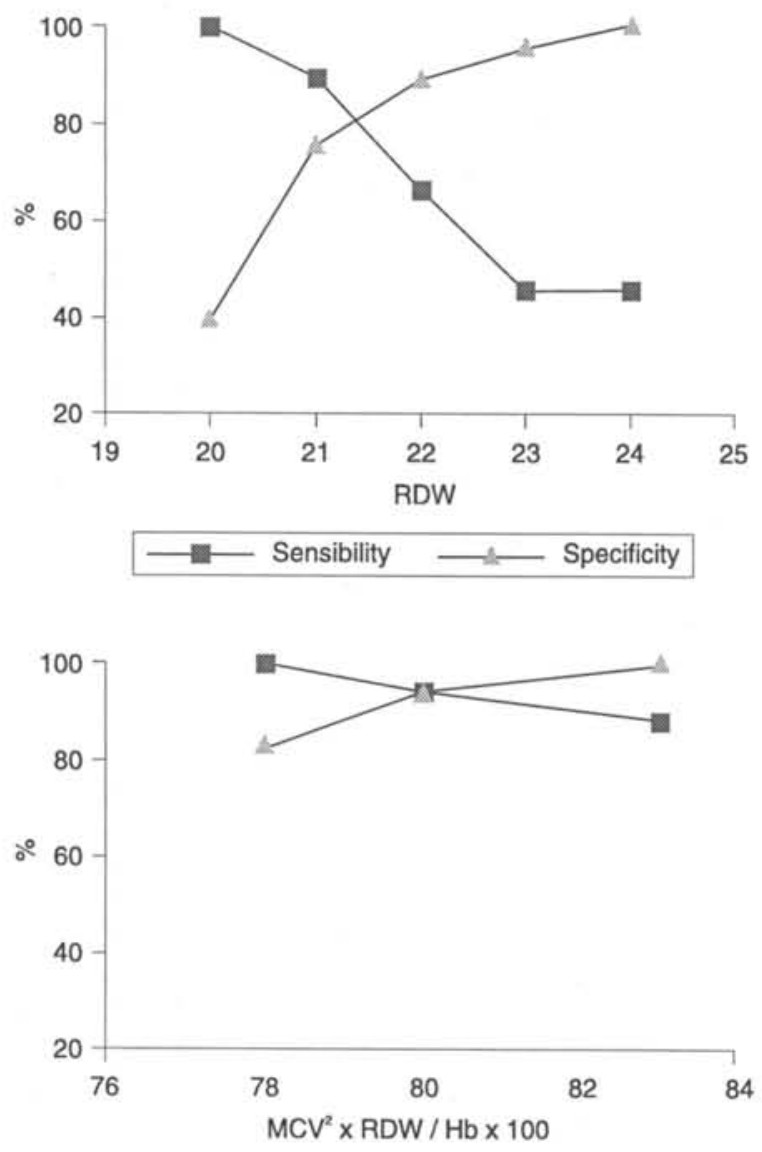

Figure 3 - Proportional of correctly diagnosed iron deficiency anemia patients according different decision levels for the discriminant function: RDW (A) and $\mathrm{MCV}^{2} \times \mathrm{RDW} / \mathrm{Hgb} \times 100$ (B).

with iron deficiency anemia, and 97.0 percent of beta thalassemia trait patients, respectively. Thus, this discriminant function apparently is a very sensitive and specific method in the initial screening for patients with microcytic anemia. Similar results were obtained by Green and King (1989), although these authors used a different decision level to distinguish both disorders. The difference between the decision levels can be explained by several factors, including the types of eletronic counters used for the generation of red blood cells index. In this study we

\begin{tabular}{|c|c|c|c|c|}
\hline \multicolumn{5}{|c|}{$\begin{array}{c}\text { Table } 1 \\
\text { Proportion of correctly-identified cases } \\
\text { by the discriminant functions in iron deficiency } \\
\text { anemia patients (ID) and beta thalassemia trait } \\
\text { patients (THAL) }\end{array}$} \\
\hline \multirow{2}{*}{$\begin{array}{l}\text { Discriminant } \\
\text { function }\end{array}$} & \multicolumn{2}{|c|}{ Decision level } & \multicolumn{2}{|c|}{$\begin{array}{c}\text { Correctly identified } \\
\text { cases (\%) }\end{array}$} \\
\hline & ID & THAL & $\begin{array}{c}\text { ID } \\
(n=30)\end{array}$ & $\begin{array}{l}\text { THAL } \\
(n=30)\end{array}$ \\
\hline RDW & $\geq 21$ & $<21$ & 90 & 77 \\
\hline $\mathrm{MCV}^{2} \times \mathrm{RDW}$ & $\geq 80$ & $<80$ & 97 & 97 \\
\hline $\mathrm{Hgb}$ & & & & \\
\hline
\end{tabular}

used the Cell-Dyn, model 1600 CS, while Green and King (1989) used the Coulter S + IV, which may result in several differences including: the principle of the detection system used in these instruments; the selection or truncation of the events for red cells analysis; and calibration factors. Moreover, the methods used for determining the decision level were different; in this study we used the major values of sensibility and specificity, while in Green and King (1989) study the decision level was determined empirically.

Thus, the results presented in this study indicated that the red cell discriminant functions RDW and $\left(\mathrm{MCV}^{2}\right.$ $x$ RDW/Hgb $x$ 100) might be useful in the initial screening of subjects with microcytosis for distinguishing iron deficiency and beta-thalassemia trait, and may suggest which additional tests should be done to confirm the correct diagnosis.

\section{ACKNOWLEDGMENTS}

Thanks is expressed to Carmen Lúcia Rodrigues Arruda and Sandra Sousa Andrade for technical assistence. 


\section{RESUMO}

A função discriminante baseada na distribuição do tamanho dos eritrócitos (RDW) e outra função discriminante incorporando o RDW (MCV ${ }^{2} \times$ RDW/Hgb $\left.\times 100\right)$ foram determinadas em um grupo de 30 pacientes com anemia ferropriva, 30 pacientes com

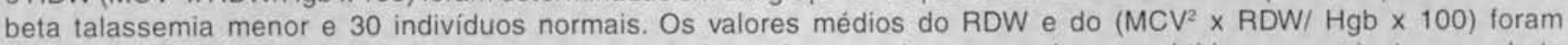
significativamente maiores em pacientes com anemia ferropriva quando comparados aos obtidos em pacientes com beta talassemia menor $(p<0.001)$. Considerando os valores de RDW iguais ou superiores a $21.0 \%$ entre os pacientes com anemia microcitica, nós identificamos corretamente $90 \%$ dos pacientes com anemia ferropriva, sendo que a sensibilidade e a especificidade do teste foram $90.0 \%$ (IC 95\%: $0.75-0.96$ ) e $77.0 \%$ (IC 95\%: $0.60-0.88$ ), respectivamente. Valores de RDW menores do que $21.0 \%$ identificaram corretamente $77.0 \%$ dos pacientes com beta talassemia menor, com sensibilidade e especificidade de $77.0 \%$ (IC $95 \%: 0.60-0.88$ ) e $90.0 \%$ (IC 95\%: $0.75-0.96$ ), respectivamente. Considerando valores de $\left(\mathrm{MCV}^{2} \times \mathrm{RDW} / \mathrm{Hgb} \times 100\right)$ maiores e menores do que $80.0 \%$ como indicativos de anemia ferropriva e beta talassemia menor, respectivamente, nós identificamos corretamente $97.0 \%$ dos pacientes de cada grupo, com sensibilidade e especificidade de 97.0 (IC 95\%; 0.84 - 0.99). Estes resultados indicaram que a função discriminante $\left(\mathrm{MCV}^{2} \times \mathrm{RDW} / \mathrm{Hgb} \times 100\right)$ é um método altamente sensivel e especifico para a triagem inicial de pacientes com anemia microcitica e é superior ao RDW para a diferenciaçāo de pacientes com anemia ferropriva daqueles com beta talassemia menor.

\section{REFERENCES}

1. Cunningham LO, Rising JA. Erythrocytic microcytosis: Clinical implications in 100 patients. Am J Med Sci 1977;273:149-55.

2. Pearson HA, O'Brien, RT MacIntosh S. Screening for thalassemia trait by electronic measurement of mean corpuscular volume. N Engl J Med 1973;288:351-3.

3. Bessman JD, Gilmer PR, Gardner FH. Improved classification of anemias by MCV and RDW. Am J Clin Pathol 1983; 80:322-6.

4. England JM, Fraser PM. Differentiation of iron deficiency from thalassemia trait by routine blood count. Lancet 1973;1:449-52.

5. England JM, Ward SM, Down MC. Microcytosis, anisocytosis and the red cell indices in iron deficiency. $\mathrm{Br} \mathrm{J}$ Haematol 1976;34:589-97.

6. Johson CS, Tegos C, Beutler E. Thalassemia minor: Routine erythrocyte measurements and differentation from iron deficiency. Am J Clin Pathol 1983;80:31-6.

7. Mentzer JR. Differentiation of iron deficiency from thalassemia trait. Lancet 1983;1:882.
8. Stephens AD. Abnormal haemoglobins and thalassemia: methods and control. Acta Haematol 1985;74:1-5.

9. Green A, King R. A new red cell discriminant incorporating volume dispersion for differentiating iron deficiency anemia from thalassemia minor. Blood Cells 1989;15:481-95.

10. Karnad A, Poskitt TR. The automated complete blood cell count. Arch Intern Med 1985;145:1270-2.

11. McClure S, Custer E, Bessman JD. High RDW is the earliest predictor of iron deficiency. Blood 1983;62 (Suppl 1):5la.

12. Miguel A, Linares M, Miguel A, Miguel-Borja JM. Red cell distribution width analysis in differentiation between iron deficiency and thalassemia minor. Acta Haemat 1988;80:59.

13. Weatherall DJ, Clegg JG. The thalassemias syndromes, 3rd ed. Oxford: II Blackwell Scientific Publications, 1981.

14. Siegel S. Nonparametric statistics. New York: Mc Graw-Hill Book Company, 1956.

15. Simon R. Confidence intervals for reporting results of clinical trials. Ann Int Med 1986;105:429-35.

16. Bessman JD, Johson RK. Erythrocyte volume distribution in normal and abnormal subjects. Blood 1975;46(3):369-79.

17. Ghionni H, Miotti TC, Camandona V. Routine erythrocyte measurements and differentiations of thalassemia minor from iron deficiency. Minerva Med 1985;76:1143-8. 